\title{
The phonology of classical Arabic meter*
}

CHRIS GOLSTON and TOMAS RIAD

\section{Abstract}

We propose a phonologically well motivated theory of metrics that avoids several problems (e.g. ternarity and center-headedness) with the traditional analysis of Arabic metrics (al-Xalīl †c. 791h; Maling 1973; Prince 1989). We propose that the content of a metrical position is universally restricted to three prosodically motivated units: $L, H, L L$, and that binarity holds at the levels of the verse foot and metron. This constrains the number of possible verse feet to nine and leads to the insight that the traditional Arabic verse feet are in reality metra (pairs of verse feet). The different degrees of popularity of the Arabic meters (cf. corpora in Vadet 1955; Stoetzer 1986; Bauer 1992), we argue, can be understood as a direct function of rhythmic well-formedness. The best meters are all iambic (Ewald 1825; Jacob 1967 [1897]; Fleisch 1956), the rhythmic advantage being that they contain no rhythmic lapse (Kager 1993), an important constraint in Arabic phonology and morphology generally (Fleisch 1956; McCarthy and Prince 1990b). Relative rhythmic well-formedness is formally expressible under a simple constraint-based analysis (cf. Prince and Smolensky 1993).

\section{Introduction}

Traditional analysis of classical Arabic meter is based on the theory of al-Xali1 (†c. 791 A.D.), the famous lexicographist, grammarian, and prosodist. His elaborate circle system remains directly influential in theories of metrics to this day, including the generative analyses of Halle (1966), Maling (1973), and Prince (1989). ${ }^{1}$ We argue against this tradition, showing that it hides a number of important generalizations about Arabic meter and violates a number of fundamental principles that regulate metrical structure in meter and in natural language. In its place we 
propose a new analysis of Arabic meter that draws directly on the iambic nature of the language and is responsible to the metrical data in a way that has not been attempted before. We call our approach prosodic metrics and ground it firmly in a restrictive theory of foot typology (Kager 1993) and constraint satisfaction (Prince and Smolensky 1993). The major points of our analysis of Arabic meter are as follows:

1. Metrical positions are maximally bimoraic.

2. Verse feet are binary.

3. The most popular Arabic meters are iambic.

We begin with a presentation of prosodic metrics (section 2) followed by individual analyses of the Arabic meters (section 3 ). We then turn to the relative popularity of the meters in two large published corpora, relating frequency directly to rhythm (section 4). We then argue against al-Xalin's analysis as formalized in Prince (1989) (section 5) and end with a brief conclusion (section 6).

\section{Prosodic metrics}

We base our theory of meter on the three claims in (1), which we jointly refer to as binarity.

(1) Binarity:

metrical position $=($ at most $)$ two moras

verse foot $=$ two metrical positions

metron $=$ two verse feet

Binarity constrains our theory at three levels. At the level of the metrical position it allows only a heavy syllable, a light syllable, or a sequence of two light syllables:

(2) Possible metrical positions:

$\mathrm{H}$ bimoraic, monosyllabic

L monomoraic, monosyllabic

LL bimoraic, disyllabic

Trimoraic (LH, HL, LLL) and larger (HH, LHL, etc.) metrical positions are not allowed in the theory. At the level of the verse foot binarity restricts us to nine $\left(3^{2}\right)$ pairs of metrical positions:

(3) Possible verse feet:

\begin{tabular}{|c|c|c|c|c|c|}
\hline$[\mathrm{L}$ & $\mathrm{H}]$ & {$[\mathrm{L}$} & $\mathrm{L}]$ & {$[\mathrm{L}$} & LL] \\
\hline$[\mathrm{H}$ & $\mathrm{H}]$ & {$[\mathrm{H}$} & L] & {$[\mathrm{H}$} & LL] \\
\hline [LL & $\mathrm{H}]$ & {$[\mathrm{LL}$} & L] & {$[\mathrm{LL}$} & LL] \\
\hline
\end{tabular}


Within this metrical space, natural classes are defined by rhythmic constraints. Thus we will show that $90 \%$ of all Classical Arabic poetry used the first three feet in (3); the remaining $10 \%$ used the middle group of two feet; and no poetry used the last group of four feet.

To define a given meter, we shall often refer to natural classes with the Greek letter variables given in (4).

(4) Natural classes of prosody:

$\{\mathrm{L}, \mathrm{H}\} \quad \sigma$ syllable

$\{\mathrm{H}, \mathrm{LL}\} \quad \phi \quad$ bimoraic foot

Thus we will characterize the set of feet $[\mathrm{L} \mathrm{H}]$ and $[\mathrm{H} \mathrm{H}]$ as simply $[\sigma \mathrm{H}]$; the set of feet $[\mathrm{LL} \mathrm{H}]$ and $[\mathrm{H} \mathrm{H}]$ as $[\phi \mathrm{H}]$; and so on. Note that these sets of feet are not distinct feet but natural classes of feet.

Our analysis of Arabic meter includes three constituents above the verse foot: the metron, the half-line, and the line. The line contains four (tetrameter), six (hexameter), or eight (octameter) metra. We will see that the metron plays a central role in Arabic meter and that it contains exactly two verse feet. A crucial element of our analysis is that what is traditionally considered a verse foot is in fact a metron (two verse feet).

In the table below, we present an overview of the 11 ancient Arabic meters (in half-lines, for simplicity). The symbol " $\emptyset$ " indicates catalexis, a metrical position in the meter that may not be filled with text. Metra that are parenthesized are left out in certain variants of a meter: thus țawil occurs in an octameter (four per half-line), kāmil in a hexameter (three per half-line) or a tetrameter (two per half-line). The meters are given in falling order of frequency, according to the older corpus in Vadet (1955). ${ }^{2}$

(5) Arabic meter

\begin{tabular}{|c|c|c|c|}
\hline & Half-lines & $\begin{array}{l}\text { Vadet I } \\
(\%)\end{array}$ & $\begin{array}{l}\text { Stoetzer } \\
(\%)\end{array}$ \\
\hline țawìl & $\mathrm{LH} \sigma \emptyset \mathrm{LH} \sigma \mathrm{H} \mathrm{LH} \sigma \emptyset \mathrm{LH} \sigma \mathrm{H}$ & 50.41 & 35 \\
\hline kāmil & $\phi \mathrm{HLH} \phi \mathrm{HLH}(\phi \mathrm{HLH})$ & 17.53 & 20 \\
\hline wāfir & $\mathrm{LH} \phi \mathrm{H} \mathrm{LH} \phi \mathrm{H}(\mathrm{LH} \phi \mathrm{H})$ & 13.74 & 14 \\
\hline basīt & $\sigma \mathrm{HLH} \sigma \emptyset \mathrm{LH} \sigma \mathrm{HLH} \sigma \emptyset \mathrm{LH}$ & 11.03 & 13 \\
\hline rajaz/sarīi & $\sigma \sigma \mathrm{LH} \sigma \sigma \mathrm{LH}(\sigma \sigma \mathrm{LH})$ & 2.93 & 3 \\
\hline mutaqārib & $\mathrm{LH} \sigma \emptyset \mathrm{LH} \sigma \emptyset \mathrm{LH} \sigma \emptyset \mathrm{LH} \sigma \emptyset$ & 2.35 & 7 \\
\hline xafîf & $\sigma \mathrm{LHH} \sigma \mathrm{HLH}(\sigma \mathrm{LHH})$ & 0.69 & 2 \\
\hline madīd & $\sigma \mathrm{LHH} \sigma \mathrm{LH} \emptyset \sigma \mathrm{LHH}(\sigma \mathrm{LH} \emptyset)$ & .43 & 0 \\
\hline ramal & $\sigma \mathrm{LHH} \sigma \mathrm{LHH}(\sigma \mathrm{LHH})$ & .43 & 2 \\
\hline munsarih & $\mathrm{H} \sigma \mathrm{LH} \mathrm{H} \sigma \mathrm{HL} \mathrm{H} \sigma \mathrm{LH}$ & .43 & 2 \\
\hline hazaj & $\mathrm{LHH} \sigma \mathrm{LHH} \sigma$ & 0 & 0 \\
\hline
\end{tabular}


The leading idea of our analysis is that the groups traditionally considered to be verse feet are in fact pairs of verse feet or metra. The crucial observation is that every Arabic metron contains at least one iambic (LH) or trochaic (HL) sequence: once these are seen as sequences rather than single elements, the binary nature of Arabic meter is obvious.

Both corpora cluster the meters into one of three classes, which we call popular (țawīl), fairly popular (kāmil, wāfir and basịt), and less popular (all other). ${ }^{3}$ We return to these classes in section 4 , where we show that they are accounted for straightforwardly under our analysis; for the present we turn to analyses of the various meters.

\section{The meters}

Most classical Arabic poetry was written in tawil 'the long'. A full line of tawil is given below with breves and macrons marking light (CV) and heavy (CVC, CVV) syllables respectively (al-Nābigha, in Arberry 1965).

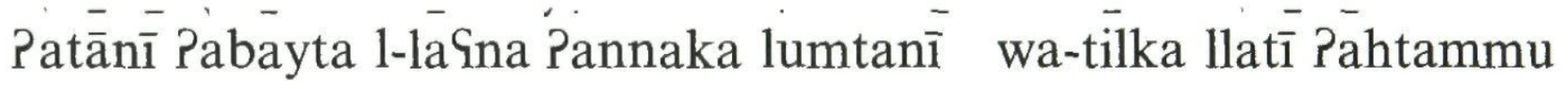
minhē wa-Pānșabù

'(news) came to me - may you spurn the curse! - that you had blamed me, and those (things) at which I am full of care and trouble'

Any account of Arabic meter involves claims about constituency. Our analysis takes the form of three lines of bracketed constituents corresponding to the verse foot, metron, and half-line (cf. [7] below). Constraints on verse feet dictate what prosodic unit or class of units may fill a metrical position: $\mathrm{L}, \mathrm{H}, \mathrm{LL}, \sigma, \phi, \mathrm{S}$, or $\emptyset$ (catalexis). ${ }^{4}$

\subsection{The iambic meters}

We begin with the relatively popular meters, which jointly account for about $90 \%$ of the poems in published corpora. In what follows we consider only half-lines for simplicity, since half-lines are identical in all relevant respects. Let us begin then with tawil.

Tawil 'the long' is an octameter ( 8 metra per line) with a constant 32 syllables per line, every other one of which is $H$ (modulo catalexis). A half-line of tawil contains four metra on our analysis, each of which contains two verse feet. The first verse foot in a metron is a proper iamb $[\mathrm{L} \mathrm{H}]$, the second alternates between an iamb and a spondee $[\mathrm{H} \mathrm{H}]$; we 
represent this alternating type of foot as $[\sigma \mathrm{H}]$. The half-line has the following structure:

(7) tawil

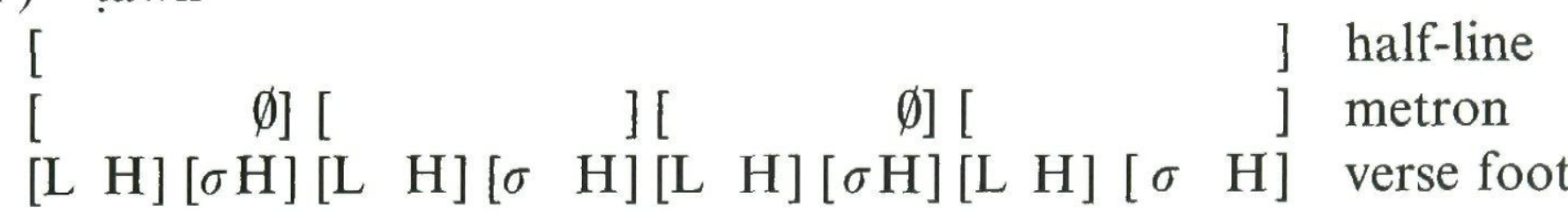

Pa tầ nī Pa bày tàl lạ na Pàn na ka lum ta nī

Note that the final metrical position of every other metron is catalectic $(\emptyset)$. The target of catalexis within the first and third metra is not arbitrary. Here as elsewhere in Arabic, it targets the least rhythmic verse foot, without removing a variable position $(\sigma$ or $\phi)$. In this case it targets the $\mathrm{H}$ of $[\sigma \mathrm{H}]$, which can give rise to stress CLASH when realized as $[\mathrm{H} \mathrm{H}]$. [L H] , the other targetable verse foot, is rhythmically impeccable.

Kāmil 'the perfect' alternates $[\phi \mathrm{H}]$ verse feet $([\mathrm{H} \mathrm{H}]$ or $[\mathrm{LL} \mathrm{H}])$ with proper iambs. Two verse feet per metron give a line of kāmil hexameter 24-30 syllables:

(8) kāmil

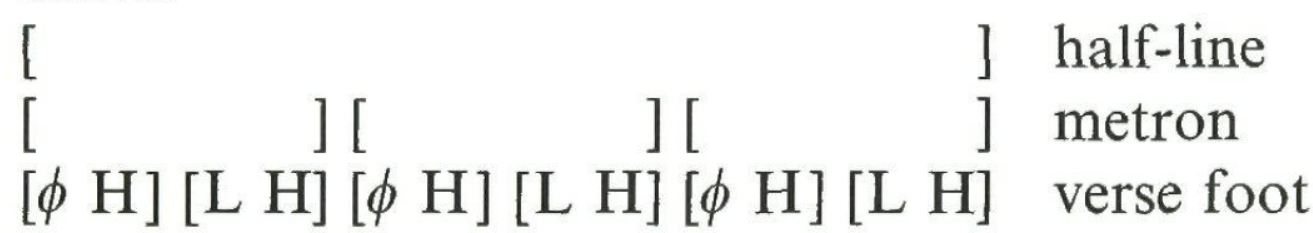

(A tetrameter occurs as well with 16-20 syllables.) Well-formed metra are thus either [HH.LH] or [LLH.LH]. The meter is binary at both the verse foot and metron level.

Wāfir 'the exuberant' uses a metron that contains the same verse feet as kāmil, but in reverse order: [LH. $\phi \mathrm{H}]$ as opposed to $[\phi \mathrm{H} . \mathrm{LH}]$. A halfline of wāfir hexameter runs as follows:

(9) wāfir

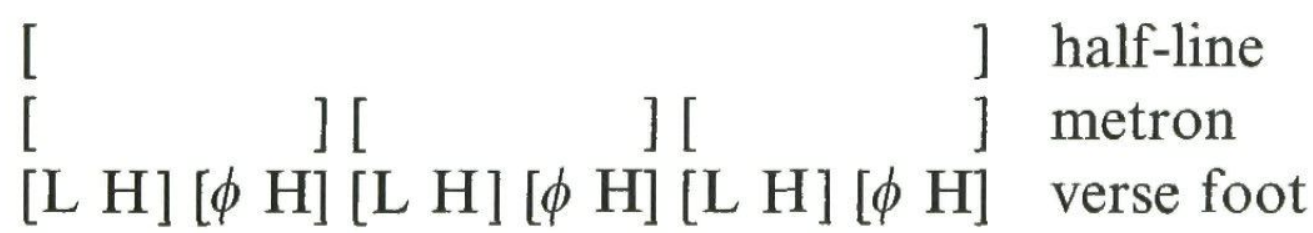

(Like kāmil, wāfir occurs as a tetrameter as well.) Kāmil and wāfir are thus alike in three ways: they use the same verse feet $([\mathrm{L} \mathrm{H}]$ and $[\phi \mathrm{H}])$, they occur in tetrameters and hexameters, and they are acatalectic.

Basit 'the outspread' and tawil form a similar pair. They use the same verse feet, occur only in octameter, and are both catalectic. They differ as follows: basit uses the verse feet in the opposite order $[\sigma \mathrm{H} . \mathrm{LH}]$ and has catalexis in even-numbered metra rather than odd. The line runs as follows: 
(10) basīt

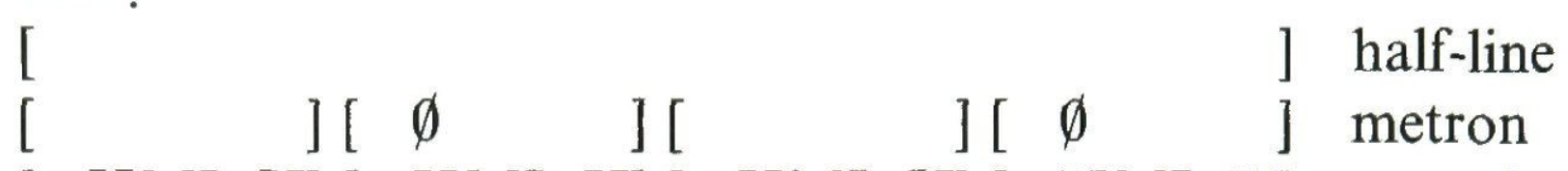

$[\sigma \mathrm{H}][\mathrm{L} \mathrm{H}][\sigma \mathrm{H}][\mathrm{L} \mathrm{H}][\sigma \mathrm{H}][\mathrm{L} \mathrm{H}][\sigma \mathrm{H}][\mathrm{L} \mathrm{H}]$ verse foot

It might look like a peculiarity of basit that catalexis does not target a peripheral metrical position but one that is metron-internal. For the purposes of classical Arabic meter, there is no need to ascribe this fact to poetic license. Rather, we understand this as the result of the following dominant constraints: (i) every metron contains at least one variable position, and (ii) catalexis targets the least rhythmic foot. Constraint (i) is exceptionless: all classical Arabic metra contain at least one variable metrical position. Strict meters like [LH.LH] or [HL.HL] do not occur. ${ }^{5}$ Consider possible variants of the catalectic metron in basit in tabular form (a dotted line separates unranked constraints).

(11) Dominant constraints:

\begin{tabular}{|c|c|c|c|}
\hline & & Variable & Rhythm \\
\hline a. & {$[\emptyset \mathrm{H}][\mathrm{L} \mathrm{H}]$} & $* !$ & \\
\hline b. & {$[\sigma \mathrm{H}][\emptyset \mathrm{H}]$} & & $* !$ \\
\hline c. & {$[\sigma \mathrm{H}][\mathrm{L} \emptyset]$} & & $* !$ \\
\hline d. & {$[\sigma \emptyset][\mathrm{L} \mathrm{H}]$} & & \\
\hline
\end{tabular}

It is not possible to satisfy (i) and (ii) unless the catalectic position is metron-internal. In (a), catalexis is peripheral and targets the rhythmically worst foot. The result is a metron $[\emptyset \mathrm{H} . \mathrm{LH}]$ with no variable position $\left({ }^{*} \mathrm{i}\right)$. Alternatives (b) and (c) have both lost their only rhythmic foot (*ii). These violations are fatal (!) because a better option exists, namely the fourth possibility, which respects both (i) and (ii).

Summarizing, the four iambic meters make use of three verse feet: $[\mathrm{L} \mathrm{H}],[\mathrm{H} \mathrm{H}]$ and [LL H]. Tawîl and basit pair [L H] with $\{[\mathrm{L} \mathrm{H}]$. $[\mathrm{H} \mathrm{H}]\}$, wāfir and kāmil pair [L H] with $\{[\mathrm{LL} \mathrm{H}],[\mathrm{H} \mathrm{H}]\}$. Tawīl and basīt are catalectic octameters; wāfir and kāmil acatalectic tetrameters or hexameters. As we will soon see, what separates these iambic meters from the following meters is that their verse feet always end in $\mathrm{H}$, never in $\mathrm{L}$ or LL. The rhythmic significance of this will become clear in section 4 .

\subsection{The old prose meter}

As shown by Maling (1973: 49), rajaz 'the trembling' and sarị 'the swift' should be conflated into one meter. It is probably the oldest of the ancient 
meters (Weil 1960: 673) and is unique among the ancient meters in having two variable positions per metron:

(12) rajaz

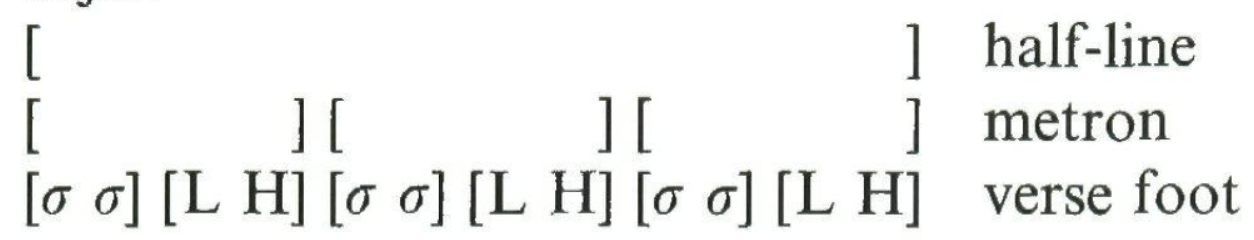

Rajaz occurs in a tetrameter and a hexameter and alternates a canonical iamb with $[\sigma \sigma]$, which can be realized as $[\mathrm{L} \mathrm{H}],[\mathrm{H} \mathrm{H}],[\mathrm{L} \mathrm{L}]$, or $[\mathrm{H} \mathrm{L}]$. The latter two realizations have no counterpart in the iambic meters, whose verse feet are always $\mathrm{H}$-final.

\subsection{The pancatalectic meter}

Mutaqārib 'the tripping' uses the catalectic metron found in tawil and, also like tawîl, occurs in an octameter. But mutaqārib is catalectic in every metron, something not found elsewhere among the ancient meters. Since catalexis occurs in every metron, it is not clear whether it is final $([\mathrm{LH} . \sigma \emptyset])$ or initial $([\emptyset \mathrm{L} . \mathrm{H} \sigma])$. We will not try to resolve this issue here, or the nature of the position targeted by catalexis, which we represent with "?". Formal analysis of mutaqārib is thus necessarily indeterminate:

(13) mutaqārib (final catalexis)

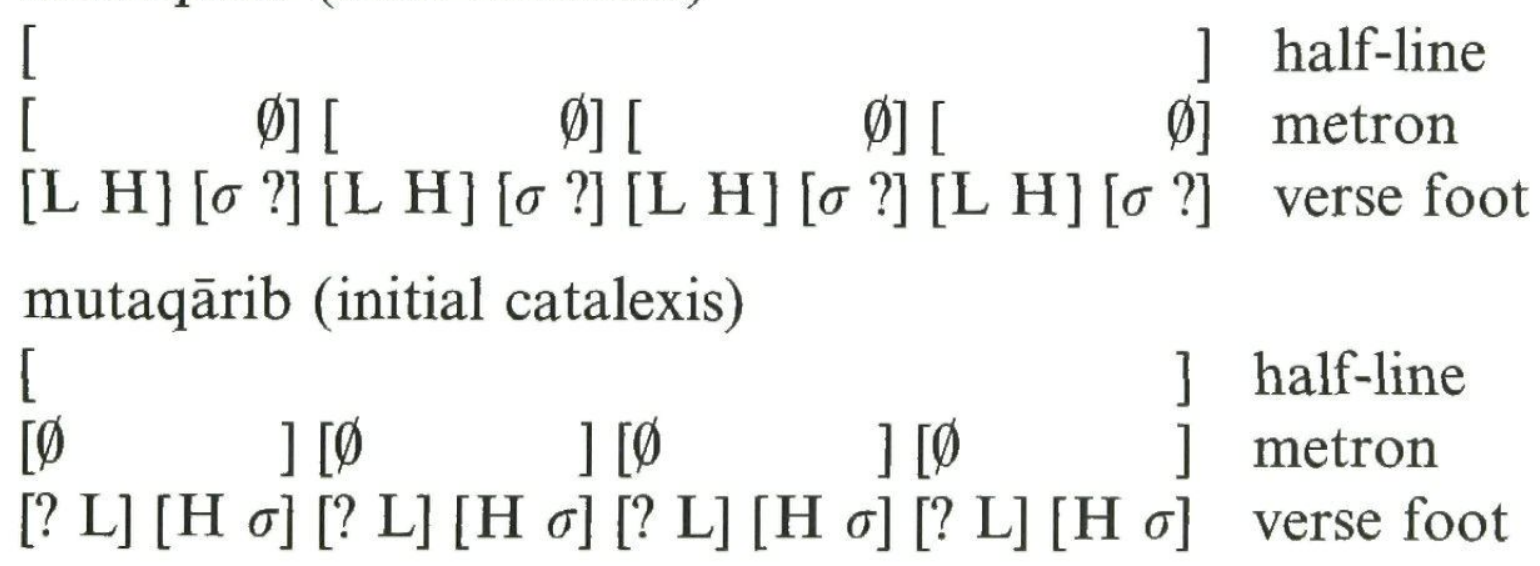

We will offer evidence below (section 4) that suggests that the second analysis is relevant in understanding the marginal status of this meter. For now we leave the issue unresolved.

\subsection{The trochaic meters}

The rest of the ancient meters all display a clear trochaic element in their verse feet. As we shall see below (section 4), this trochaicity is responsible for making these meters infrequent. The first three we will consider use a metron we have not encountered so far consisting of two feet, alternat- 
ing $[\sigma \mathrm{L}]$ and nonalternating $[\mathrm{H} \mathrm{H}]$. Xafif 'the nimble' alternates this $[\sigma \mathrm{L} . \mathrm{HH}]$ metron with the acatalectic basit metron $[\sigma \emptyset . \mathrm{LH}]$ in tetrameter and hexameter:

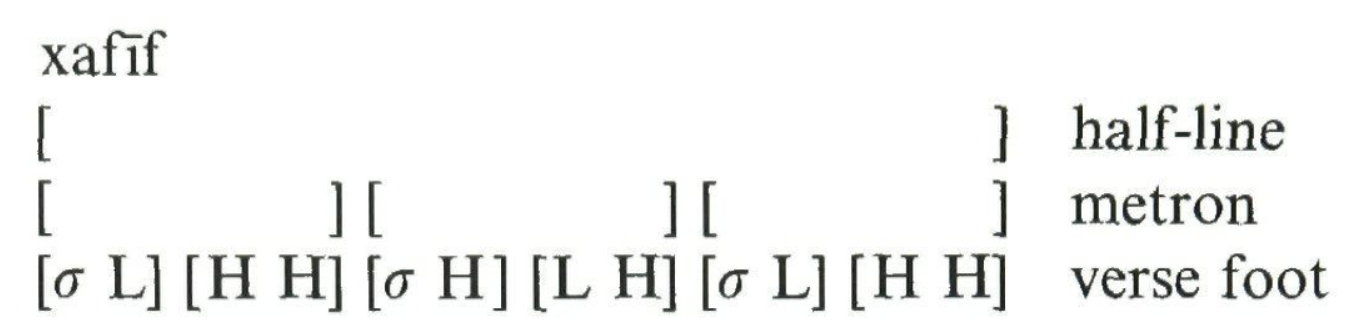

Madid 'the extended' alternates the $[\sigma \mathrm{L} . \mathrm{HH}]$ metron with a catalectic basịt metron $[\sigma \emptyset . \mathrm{LH}]$ and occurs in hexameter and octameter:

(15) madīd

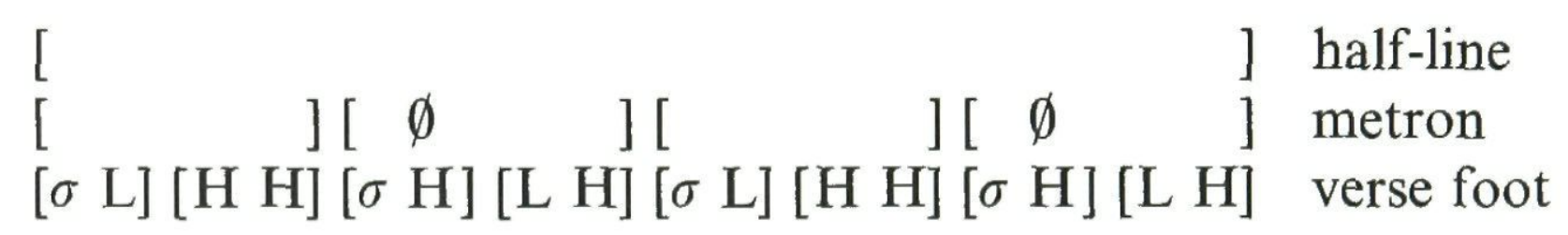

Ramal 'the running' uses the $[\sigma \mathrm{L} . \mathrm{HH}]$ metron by itself in hexameter and tetrameter:

(16) ramal

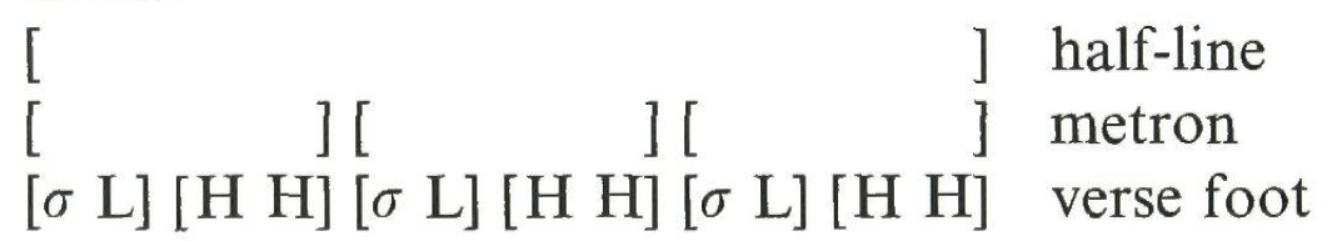

Note that the $[\mathrm{H} \mathrm{H}]$ verse foot used in all three of these meters is inherently arhythmic because it contains a stress clash; and that the $[\sigma \mathrm{L}]$ verse foot contains a potential stress lapse.

The last two ancient meters are munsarih 'the flowing' and hazaj 'the trilling' Munsarih uses three feet: variable $[\mathrm{H} \sigma]$, iambic $[\mathrm{L} \mathrm{H}]$, and trochaic $[\mathrm{H} \mathrm{L}]$ in a hexameter with alternating metra:

(17) munsarih

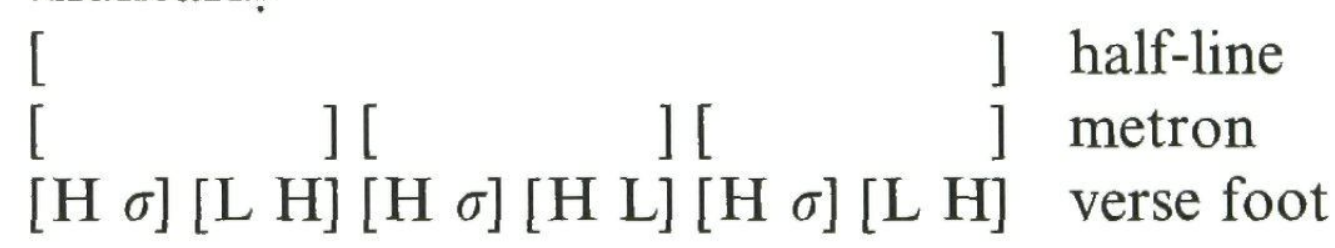

Hazaj uses iambic $[\mathrm{L} \mathrm{H}]$ and variable $[\mathrm{H} \sigma]$ in a tetrameter with uniform metra:

(18) hazaj

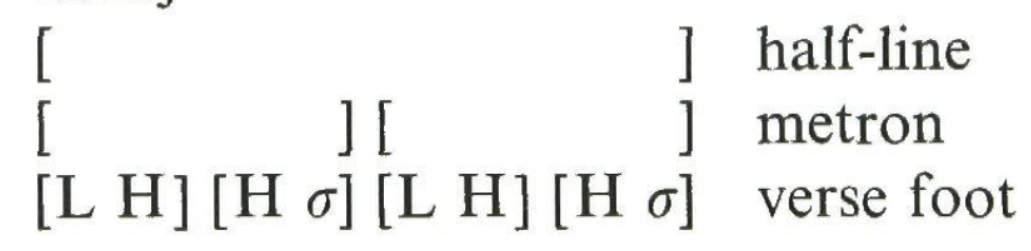

Both of these meters are marginal. 


\subsection{The nonancient meters}

The nonancient meters are of dubious origin. Some researchers hold al-Xalil responsible for inventing three of them in part because they appear to fill out some gaps in the Xalilian circle system (Guyard 1876). As we will now see, the nonancient meters bear a number of close affinities to their ancient forebears.

Muqtadab 'the lopped' is basically a tetrameter version of the munsarih, (17); the only rhythmic difference is that muqtadab begins its alternating metra with trochaic $[\mathrm{H} \sigma . \mathrm{HL}]$ where munsarih begins its alternating metra with iambic $[\mathrm{H} \sigma . \mathrm{LH}]$.

(19) muqtadab

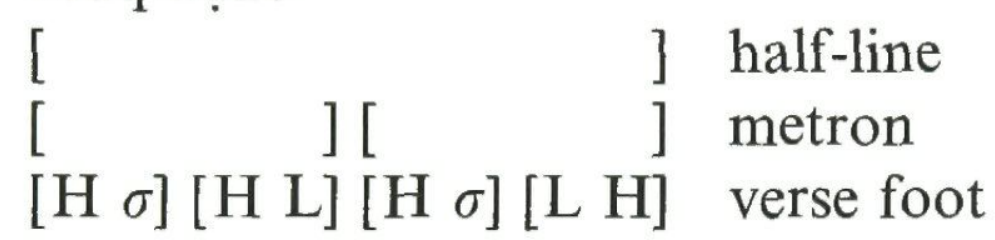

Similarly with mujta $\theta \theta$ 'the amputated', a tetrameter version of xafiff, (14):

(20) mujta $\theta \theta$

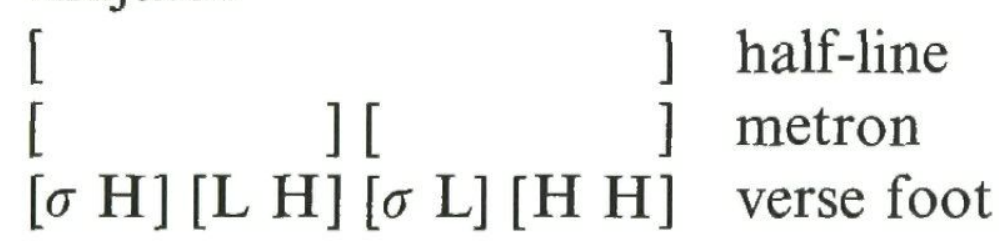

Again, the rhythmic difference comes in the order of metra: mujta $\theta \theta$ begins its alternating metra with iambic $[\sigma \mathrm{H} . \mathrm{LH}]$, xafiff with $[\sigma \mathrm{L} . \mathrm{HH}]$.

Muḍārị makes use of four distinct verse feet: iambic [L H] trochaic $[\mathrm{H} \mathrm{L}]$, and two alternating feet, $[\sigma \sigma]$ and $[\mathrm{H} \sigma]$.

(21) muḍārị

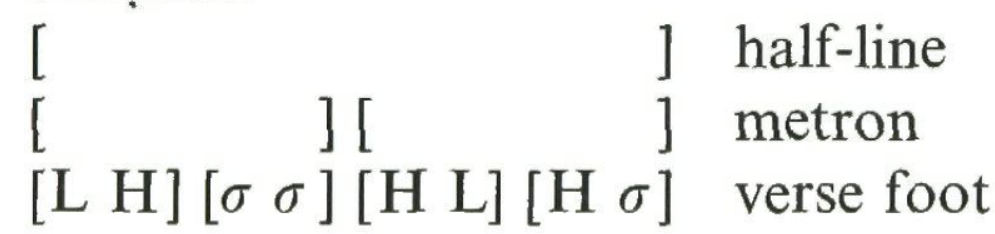

The meter is understandably quite rare (Wright 1955 [1898]: 365).

This leaves us with mutadārik, a pancatalectic meter like ancient mutaqārib. It is ambiguous between the two following analyses:

(22) mutadārik (final catalexis)

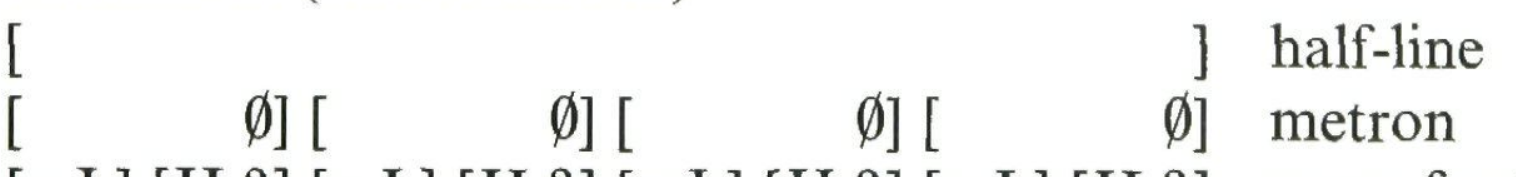

$[\sigma \mathrm{L}][\mathrm{H}$ ?] $[\sigma \mathrm{L}][\mathrm{H}$ ?] $[\sigma \mathrm{L}][\mathrm{H}$ ?] $[\sigma \mathrm{L}][\mathrm{H}$ ?] verse foot

mutadārik (initial catalexis)

] half-line 


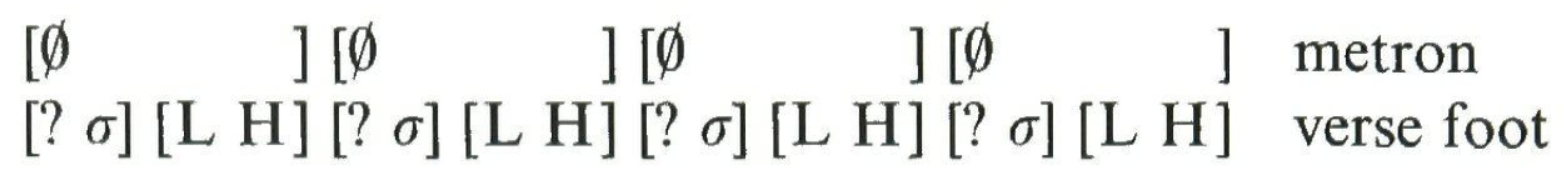

As with mutaqārib, we will not try to force the matter of which analysis in (22) is correct. But we will use the ambiguous nature of a pancatalectic meter to account for the fact that mutaqārib and mutadārik never became major meters.

This concludes our analysis of the Arabic meters. As can be seen from the above exposé, all of the meters use natural classes of the universal set of verse feet in (3). None of the meters requires ternary structure of any kind or terminal metrical positions other than $\mathrm{H}$, L, or LL.

\section{Statistical evidence}

We now turn to the statistical figures of the Vadet I (1955) and Stoetzer (1986) corpora. The point is to provide an account of the relative popularity of the different meters, a statistical distribution any analysis should be able to describe.

The particularly striking fact is that our four iambic meters make up $80-90 \%$ of classical Arabic poetry. Much previous work in Arabic metrics has stressed that the dominant consideration in Arabic meter is iambicity (Ewald 1825; Jacob 1967 [1897]; Wright 1955 [1898]; Fleisch 1956); but we believe ours is the first to capture this formally. We will explain the iambic preference in terms of rhythm.

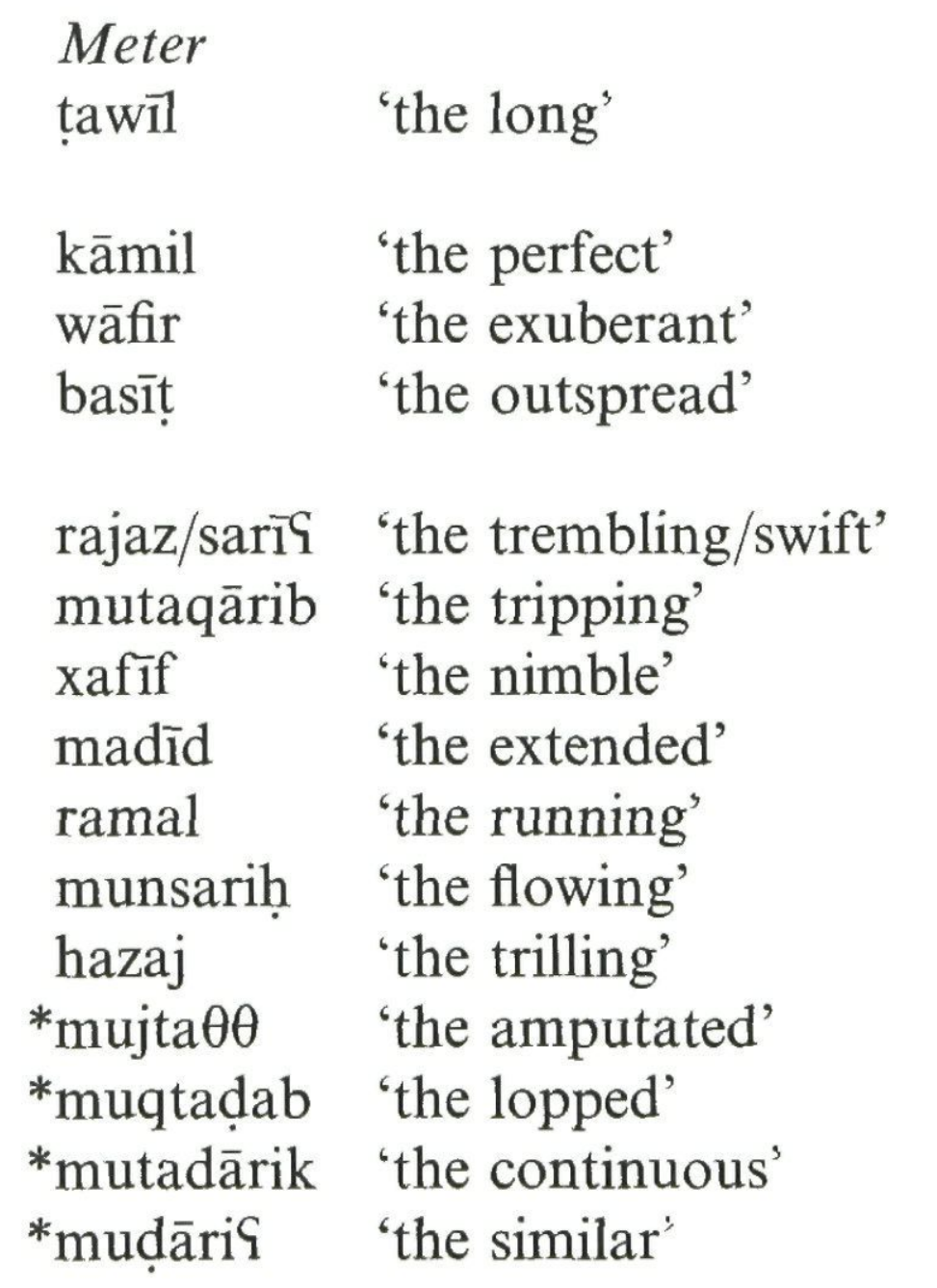

Vadet I (\%) Stoetzer (\%) $50.41 \quad 35$.

17.5320 .

$13.74 \quad 14$.

$11.03 \quad 13$.

2.923.

2.357 .

.692 .

.430.

.432 .

.432 .

$<.43 \quad 0$.

$<.43 \quad 0$.

$<.43 \quad 0$.

$<.43 \quad 0$.

$<.43 \quad 0$. 
The dotted lines mark major splits in terms of frequencies. In the following sections we will give a formal account of the splits between the four iambic meters and the rest (section 4.1) and between tawil and the remaining iambic meters (section 4.2). But first a brief description of the corpora.

Vadet (1955) contains two corpora, one older, from the first to third centuries A.D. (I), and one younger, from the seventh to ninth centuries A.D. (II). The figures used here are based on the older corpus, which contains nearly 2,300 poems and fragments, and which represents Bedouin poetry. The percentages refer to poems and fragments of poems from so-called divans (collections of poems by poets of the same tribal affinity). The calculations are those of Fleisch (1956), except that we have conflated the figures for rajaz and sarī9. ${ }^{6}$ Fleisch moves one anthology of poems from Vadet's corpus I to the later corpus II, on grounds of its city-related themes.

Stoetzer (1986) is a corpus of 130 poems from al-Xalil's lifetime (eighth century A.D.). As in the Vadet (1955) corpus, the percentages given are based on the number of poems in a given meter within the corpus. ${ }^{7}$

Vadet cautions us not to expect to find a direct reflection of Arabic metrics generally in his corpus, since the poetry is collected from famous anthologies only. As Stoetzer observes (1986: 151), some anthologies contain selected fragments "pruned of all weak and unessential verses." In view of this, the Stoetzer figures provide useful reference, since he consciously endeavors to make his corpus representative.

A couple of other corpora, Bauer (1992) and Vadet II (1955), both of which contain later text, confirm the general pattern: tawil at the top; kāmil, wāfir, and basịt near the top; the rest lower down.

\subsection{Why iambic meters are best}

The four best attested meters all contain an iambic core [L H]. We attribute nothing mystical to the well-formedness of $[\mathrm{L} \mathrm{H}]$ but note that it is the only combination of Ls and Hs that violates neither CLASH nor LAPSE. These rhythmic notions are universal and familiar from work on linguistic rhythm (Liberman and Prince 1977; Prince 1983; Nespor and Vogel 1989; Kager 1993). ${ }^{8}$

Let us first see why LH is rhythmically perfect. Hayes (1985) observes an asymmetry in quantity-sensitive stress systems: uneven iambs ( $\mathrm{LH})$ are preferred, but uneven trochees (HL) are not - a well-formed trochee should be bimoraic LL. In order to explain this, Kager (1993) notes that uneven iambs and uneven trochees have different moraic structure and 
that the uneven trochee contains a lapse (underlined) at the moraic level, while the uneven iamb does not:

(24) Moraic lapse

a. uneven trochee b. uneven iamb

$\begin{array}{llll}\mathbf{x} & & \mathbf{x} . & \text { prominence } \\ \mu \mu & \mu & \mu \mu \mu & \text { moras } \\ \mathrm{H} & \mathrm{L} & \mathrm{L} \mathrm{H} & \end{array}$

Given that the first of two moras in a syllable is the prominent one, HL results in two adjacent moras neither of which is prominent. ${ }^{9}$ A sequence $\mathrm{HL}$ is thus rhythmically ill-formed and meters are punished for containing it.

We assume that constraints on LAPSE and CLASH are fundamentally local in nature, such that violations are felt more keenly within verse feet than across them (within metra). We take this to be a universal feature of rhythmic evaluation. For the purposes of Classical Arabic, it is relevant to refer to two domains, namely the verse foot (CLASH-FT, LAPSE-FT) and the metron (CLASH-MTN, LAPSE-MTN). The relevance of locality is brought out formally by the ranking of the verse-foot constraints above the metron constraints (as marked by the solid line between them in [28], below).

LAPSE-FT is violated by any meter with $[\mathrm{H} \mathrm{L}],[\mathrm{H} \sigma],[\sigma \mathrm{L}]$, or $[\sigma \sigma]$ verse feet, each of which can give rise to a $\mathrm{HL}$ sequence within a verse foot; it cannot be violated by any verse foot that ends in $\mathrm{H}$ : [L H], [LL H], $[\mathrm{H} \mathrm{H}]$ all respect LAPSE-FT. This is what separates the four iambic meters from the rest:

LAPSE-FT ${ }^{10}$

\begin{tabular}{|c|c|c|c|}
\hline$\%$ & Meter & shape & LAPSE-FT \\
\hline 50.41 & tawil & {$[\mathrm{LH} . \sigma \emptyset],[\mathrm{LH} . \sigma \mathrm{H}]$} & \\
\hline 17.53 & kāmil & {$[\phi \mathrm{H} . \mathrm{LH}]$} & \\
\hline 13.74 & wāfir & {$[\mathrm{LH} . \phi \mathrm{H}]$} & \\
\hline 11.03 & basìt & {$[\sigma \mathrm{H} . \mathrm{LH}],[\sigma \emptyset . \mathrm{LH}]$} & \\
\hline 2.92 & rajaz/sarīi & {$[\underline{\sigma \sigma} . \mathrm{LH}]$} & $*$ \\
\hline 2.35 & mutaqārib & {$[\mathrm{LH} . \sigma \emptyset]$ or $[\emptyset \mathrm{L} . \underline{\mathrm{H} \sigma}]$} & $*$ \\
\hline .69 & xafif & {$[\underline{\sigma L} . \mathrm{HH}],[\sigma \mathrm{H} . \mathrm{LH}]$} & $*$ \\
\hline 43 & ramal & {$[\underline{\sigma \mathrm{L}} . \mathrm{HH}]$} & $*$ \\
\hline
\end{tabular}




\begin{tabular}{|c|c|c|c|}
\hline .43 & madīd & {$[\underline{\sigma \mathrm{L}} . \mathrm{HH}],[\sigma \mathrm{L} . \mathrm{H} \emptyset]$} & $*$ \\
\hline .43 & munsarih & {$[\underline{\mathrm{H} \sigma} . \mathrm{LH}],[\underline{\mathrm{H} \sigma} . \underline{\mathrm{HL}}]$} & $*$ \\
\hline$<.43$ & hazaj & {$[\mathrm{LH} . \underline{\mathrm{H} \sigma}]$} & $*$ \\
\hline$<.43$ & *mutadārik & {$[\underline{\sigma \mathrm{L}} . \mathrm{H} \emptyset]$ or $[\emptyset \sigma . \mathrm{LH}]$} & $*$ \\
\hline$<.43$ & *muqtaḍab & {$[\underline{\mathrm{H} \sigma} . \underline{\mathrm{HL}}],[\underline{\mathrm{H} \sigma} \cdot \mathrm{LH}]$} & $*$ \\
\hline$<.43$ & ${ }^{*}$ mujta $\theta \theta$ & {$[\sigma \mathrm{H} . \mathrm{LH}],[\underline{\sigma \mathrm{L}} . \mathrm{HH}]$} & $*$ \\
\hline$<.43$ & *muḍārị & {$[\mathrm{LH} . \underline{\sigma \sigma}],[\underline{\mathrm{HL}} . \underline{\mathrm{H} \sigma}]$} & $*$ \\
\hline
\end{tabular}

Avoidance of LAPSE-FT is what makes țawìl, kāmil, wāfir, and basịt better attested than the other meters.

Recall that the pancatalectic meters mutaqārib and (nonancient) mutadārik are ambiguous between initial and final catalexis:

$\begin{array}{llll}\text { mutaqārib } & {[\mathrm{LH} . \sigma \emptyset]} & \text { or } & {[\emptyset \mathrm{L} . \underline{\mathrm{H} \sigma}]} \\ \text { mutadārik } & {[\underline{\sigma \mathrm{L}} . \mathrm{H} \emptyset]} & \text { or } & {[\emptyset \sigma . \mathrm{LH}]}\end{array}$

We understand the low occurrence of both meters as follows: since both initial and final catalexis are possible, there is no guarantee that either meter will be perceived without violation of LAPSE-FT. Only meters that unambiguously avoid LAPSE-FT occur in more than $10 \%$ of Arabic poetry.

\subsection{Why tawill is better than the other iambic meters}

All four iambic meters are equally rhythmic with respect to LAPSE-FT. However, in all of the corpora we know of (Vadet I and II, 1955; Stoetzer 1986; Bauer 1992) tawil is markedly more frequent than the other iambic meters:

(27) Top four in four corpora (\%):

$\begin{array}{lllll} & \text { Vadet I } & \text { Vadet II } & \text { Stoetzer } & \text { Bauer } \\ \text { tawī } & 50 & 21 & 35 & 39 \\ \text { kāmil } & 17 & 17 & 20 & 11 \\ \text { wāfir } & 14 & 10 & 14 & 14 \\ \text { basịt } & 11 & 13 & 13 & 11\end{array}$

The internal ranking among kāmil, wāfir, and basịt is insecure, but the consistently high ranking of tawil requires explanation. ${ }^{11}$ We propose that tawil is the most common meter because it never consistently violates 
any rhythmic constraint. By contrast, each of the other iambic meters does, as shown below.

(28) Sporadic and consistent violations of rhythmic constraints:

\begin{tabular}{|c|c|c|c|c|c|}
\hline Meter & Metra & LAPSE-FT & CLASH-FT & LAPSE-MTN & CLASH-MTN \\
\hline țawil & {$[\mathrm{LH} . \sigma \mathrm{H}]$} & & $(*)$ & $(*)$ & $(*)$ \\
\hline kāmil & {$[\phi \underline{\mathrm{H}} . \mathbf{L H}]$} & & $(*)$ & $*$ & \\
\hline wāfir & {$[\mathrm{LH}, \phi \mathrm{H}]$} & & $(*)$ & & $*$ \\
\hline basīt & {$[\sigma \underline{\mathrm{H}} . \mathbf{L} \mathrm{H}]$} & & $(*)$ & $*$ & \\
\hline
\end{tabular}

Within the verse foot, each of the iambic meters is equally rhythmic. None violates LAPSE-FT and each occasionally violates CLASH-FT by virtue of a $[\sigma \mathrm{H}]$ or a $[\phi \mathrm{H}]$ verse foot, which can be realized as $\mathrm{HH}$. Where the meters differ rhythmically is between verse feet, at the level of the metron.

Looking only at interfoot sequences, we see that a tawil metron violates either LAPSE-MTN, that is, H.L, or CLASH-MTN, that is, H.H, but consistently violates neither. Kāmil and basiț, on the other hand, consistently violate LAPSE-MTN and wāfir consistently violates CLASHMTN. ${ }^{12}$ None of these meters is rhythmically perfect, but three of them have some rhythmic constraint that they consistently violate. This difference, consistent violation versus occasional violation of some constraint, makes kāmil, wāfir, and basịt less well attested than țawîl.

\section{Al-XaПilian metrics}

We turn now to a brief exposition of the traditional analysis of Arabic verse, recently formalized in Prince (1989). We will argue that it hides the generalizations our analysis brings out, is at odds with what we know about prosodic structure in natural language, and is embedded in a much less restrictive theory of meter.

The verse-foot unit of al-Xalil consists of two basic types of element, peg $(\mathrm{P} / \mathrm{Q})$ and cord $(\mathrm{K} / \mathrm{L})$. Pegs are heads, cords dependents, and their basic shapes are given below.

(29) Traditional units of classical Arabic meter

$$
\begin{array}{ll}
\text { pegs: } & \mathrm{P}=\mathrm{LH} \\
\mathrm{Q} & =\mathrm{HL} \quad \text { (i.e. } \mathrm{P} \text { reversed) } \\
\text { cords: } & \mathrm{K}=\mathrm{H} \\
\mathrm{L} & =\mathrm{LL} \quad \text { (i.e. } \mathrm{K} \text { resolved) } \\
& (\mathrm{k}=\sigma)
\end{array}
$$


We have included the lower case $\mathrm{k}$ to denote cord positions that alternate between light and heavy syllables, reserving upper case $\mathrm{K}$ for the systematically heavy positions (cf. Prince 1989: 77f.; Ewald 1825, 1833; Wright 1955 [1898]). In the table below, the meters are presented in half-lines. Information of circle and name is provided, as well as rough Greek equivalents for the various verse-foot types (following Prince 1989).

(30) Al-Xalil's analysis $(*=$ nonancient and rare)

\begin{tabular}{|c|c|c|c|}
\hline Circle & Meter & $\begin{array}{l}\text { Traditional verse feet } \\
\text { in half-lines }\end{array}$ & Greek term \\
\hline \multirow[t]{3}{*}{ I } & tawi & Pk PkK Pk PkK & dactyl \\
\hline & basit & $\mathrm{kKP} \mathrm{kP} \mathrm{kKP} \mathrm{kP}$ & anapest \\
\hline & madīd & kPK kP kPK (kP) & amphibrach \\
\hline \multirow[t]{2}{*}{ II } & wāfir & PLK PLK (PLK) & dactyl \\
\hline & kāmil & LKP LKP (LKP) & anapest \\
\hline \multirow[t]{3}{*}{ III } & hazaj & PKk PKk & dactyl \\
\hline & rajaz/sarī & kkP kkP (kkP) & anapest \\
\hline & ramal & kPK kPK (kPK) & amphibrach \\
\hline \multirow[t]{6}{*}{ IV } & munsarih & $\mathrm{KkP}$ KkQ KkP & anapest \\
\hline & xafif & kPK kQK (kPK) & amphibrach \\
\hline & *muqtaḍab & KkQ KkP & anapest \\
\hline & ${ }^{*}$ mujta $\theta \theta$ & $\mathrm{kQK} \mathrm{kPK}$ & amphibrach \\
\hline & *muḍārị & Pkk QKk & dactyl \\
\hline & (sarị & kkP kkP kkQ) & anapest \\
\hline \multirow[t]{2}{*}{ V } & mutaqārib & $\mathrm{Pk} \mathrm{Pk} \mathrm{Pk} \mathrm{Pk}$ & trochee \\
\hline & *mutadārik & $\mathrm{kP}$ kP kP kP & iamb \\
\hline
\end{tabular}

Al-Xalil's circle system is generated by shifting the P (or Q) around in the basic group of three positions. Note that some meters alternate longer groups $(\mathrm{PkK})$ with shorter, catalectic groups $(\mathrm{Pk})$ with one metrical position suppressed.

The half-line of tawil, given in (7) above, gets the following structure in al-Xalil's theory.

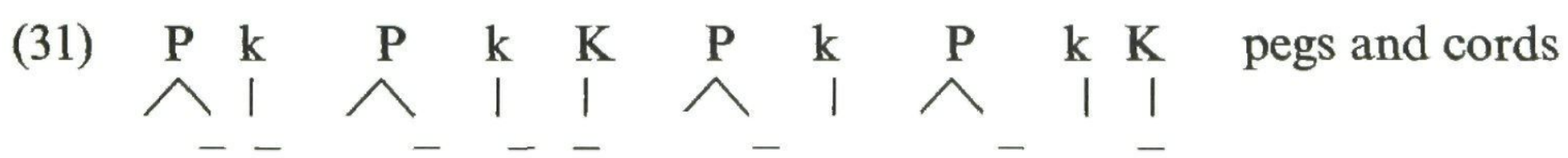

Pa tā $\overline{\mathrm{n}}$ Pa bay tal laS na Pan na ka lum ta $\overline{\mathrm{n}}$

Prince (1989) analyzes the Xalilian groups (kP, PKk, PkK, etc.) as verse feet and subjects them to a constraint on binarity. This is straightforward for a foot like $\mathrm{kP}$; but ternary feet like PKk require recursive prosodic structure, with one nonbranching daughter $[\mathrm{P}]$ and one branching daugh- 
ter $[\mathrm{Kk}]$. In some sense this invokes only binary structure, since no node has three daughters; but each such verse foot has three terminal metrical positions. In terms of number of metrical positions per foot, Prince's system has ternary as well as binary feet. Below, our sample half-line occurs in the Prince representation. The tawil metron is ambiguous, and we have - arbitrarily - used both variants below, for illustration. Prince assumes that the metron on the left is the likely one for tawil (1989: 72).
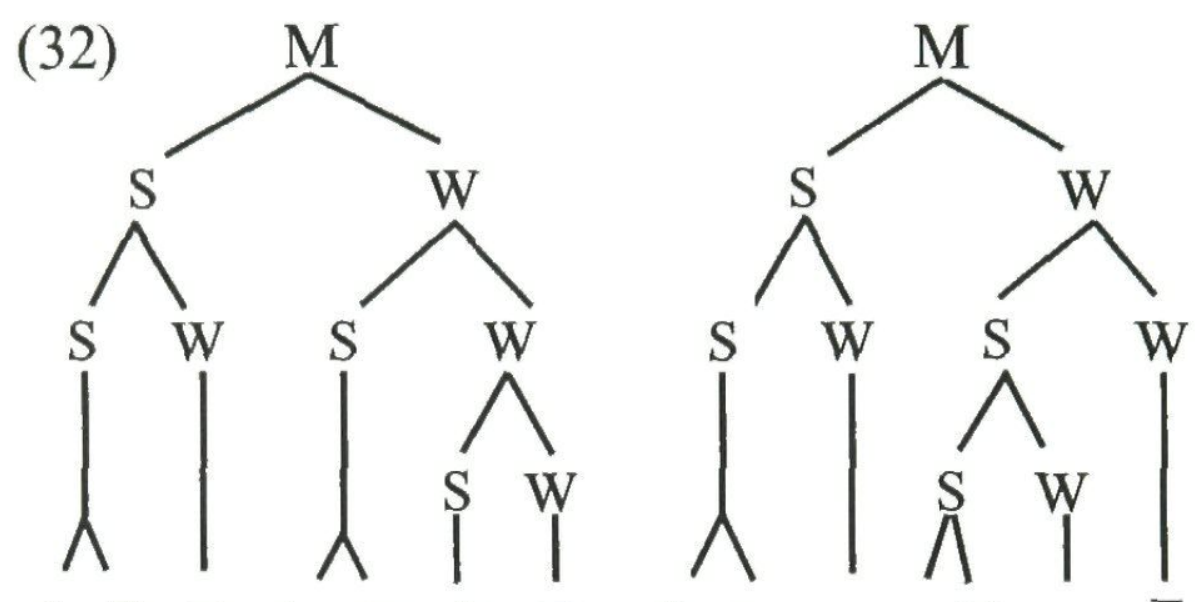

metron

verse foot

METRICAL POSITIONS metrical positions

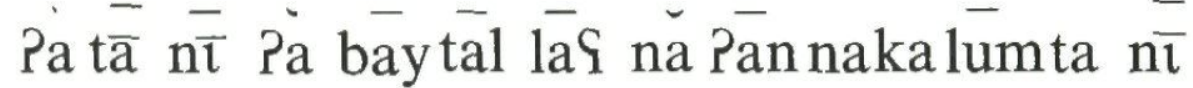

As seen, Prince retains al-Xalil's structure quite faithfully; for example, the syllables contained in the Xalinian peg (P) are still treated as one single metrical position, of either dignity. Note also that a half-line here consists of two metra, whereas our analysis claims four metra per halfline.

We turn now to four problems we see with this analysis.

\subsection{Frequency}

As we have seen, the iambic meters make up about $80-90 \%$ of Arabic verse. This fact must find some system-internal explanation, since genrerelated variation of Arabic meter is limited. ${ }^{13}$ Prince's analysis fails to expose any formal properties that can be used to set the four popular meters apart from the rest. Looking at left-, right-, or center-headed meters fails to group țawìl, basịt, wāfir, and kāmil together; nor does looking at P-meters, Q-meters, or L-meters; nor does looking at dactylic, anapestic, amphibrachic, etc., meters.

Our analysis, on the other hand, identifies the critical property as iambicity and provides a principled explanation for it in terms of moraic LAPSE. This connects the iambic preference in meter to a well-established iambic preference in Arabic phonology and morphology (Fleisch 1956; McCarthy and Prince 1990a, 1990b). The only iambic meter on Prince's analysis is mutadārik, both nonancient and rare. 


\subsection{Ternarity and center-headedness}

Prince's analysis involves both binary $(\mathrm{Pk}, \mathrm{kP})$ and ternary $(\mathrm{PkK}, \mathrm{KkQ})$ verse feet. If any relationship is to be made between meter and phonology in general, or between the meter and the phonology of Arabic, this comes as an unwelcome surprise. Ternary feet are extremely marginal in the phonologies of the world (Hayes 1995 and references therein); they are nonexistent in Arabic phonology and morphology (McCarthy 1979; McCarthy and Prince 1986, 1990a, 1990b); and they are otherwise completely marginal in meter (Hayes 1988). All three considerations make a thoroughgoing analysis of Arabic meter implausible.

A distinct concern arises with the center-headed feet Prince's analysis counters: $\mathrm{kPK}, \mathrm{kQK}$. There is very little evidence for center-headed feet in phonology (Hayes 1995) or prosodic morphology generally (McCarthy and Prince 1986) and none at all in Arabic. Again, if we are to understand meter in terms of natural language structure the traditional analysis is only a hindrance.

A related objection, already discussed, is that the traditional analysis completely obscures the observation, already made by Ewald (1825) and Jacob (1967 [1897]: 188), that Arabic meter is predominantly iambic. According to Prince's system, the most common types of meter are analyzed as anapestic (basịt, kāmil) or dactylic (țawî1, wāfir), two types of structure completely at odds with Arabic grammar, which has a strong preference for iambic structure (Fleisch 1956; McCarthy 1981; McCarthy and Prince 1990a, 1990b).

\subsection{Units of prosody}

Prince's analysis places no substantive constraints on what elements can occupy a (terminal) metrical position and thus lacks explanatory force. He makes use of five: L, H, LL, HL, and LH. The first three are those that we have used as well. HL is a suspect unit of prosody: typological work leaves little doubt that the uneven trochee (traditional Q) is not a basic unit of rhythmic analysis in the languages of the world (Hayes 1985, 1995). Similar doubt has recently been cast on the existence of LH (traditional P) feet in phonology by Kager (1993), who argues that all linguistic feet are maximally binary.

\subsection{Occam's Razor}

Prince's system requires an astonishingly high number of possible versefoot types and admits many more. Binary feet alone account for 25 
possible foot types, given the five discrete prosodic categories Prince uses in his analysis ( $\mathrm{L}, \mathrm{H}, \mathrm{LL}, \mathrm{HL}, \mathrm{LH})$. Left-branching ternary feet account for an additional 125 types, as do right-branching ternary feet. The resulting set of allowable verse feet is an ungainly 275 :

275 possible verse feet

$\begin{array}{lllrr}\text { binary } & 5^{2} & {[\mathrm{M}} & \mathrm{M}] & 25 \\ \text { split binary } & 5^{3} & {[\mathrm{MM}} & \mathrm{M}] & 125 \\ & 5^{3} & {[\mathrm{M}} & \mathrm{MM}] & +\underline{125} \\ & & & & 275\end{array}$

An analytical space this large provides little in the way of a restrictive analysis.

\subsection{Discussion}

It should now be clear how these four problems are related and how prosodic metrics avoids them all. The heart of the issue is constraining terminal metrical positions. Once we disallow LH (P) and HL (Q) as basic units of analysis we are forced to see that a meter like tawil is not ternary $(\mathrm{PkK})$ but perfectly binary $(\mathrm{LH} . \sigma \mathrm{H})$. The alleged ternarity of Arabic meter rests on a fundamental mistake in basic analysis: once LH and HL are treated as complex, ternarity disappears from the system immediately. ${ }^{14}$

Instead of five basic units of analysis we have three; instead of binarity and ternarity we have only binarity. This more restrictive approach is more explanatory as well: it immediately characterizes the top four meters as iambic, precisely what one expects from meter in a predominantly iambic language like Arabic.

\section{Conclusion}

We have presented an analysis of classical Arabic meter in which metrical positions are maximally bimoraic and metrical structure is binary and nonrecursive. Using a proper subset of the analytical devices found in Prince's (1989) analysis (no ternary structures, no use of LH or HL as basic units) we are able to formally characterize the best attested meters as iambic and relate their popularity directly to the grammar of Arabic and to universal principles of rhythmic organization.

The central insight is that the traditional units $P$ and $Q$ are not basic but internally complex. This removes all ternarity from the system and 
foregrounds the iambic nature of the top meters. Prosodic metrics gives us a way of understanding Arabic meter in terms of the structure of Arabic and in terms of the structure of language generally.

\author{
Received 23 October 1995 \\ Revised version received \\ 11 June 1996
}

\author{
California State University, \\ Fresno \\ Stockholm University
}

\section{Notes}

* We would like to thank the audiences at Trend 1 Santa Cruz 1993, LSA San Diego 1994, Katholieke Universiteit Nijmegen 1994, and the American University in Cairo 1994. Thanks also to Eva Riad and two anonymous reviewers, whose comments have substantially improved the paper. Golston's part of this research was funded by the German research project SFB 282. Correspondence addresses: Chris Golston, Department of Linguistics, California State University Fresno, Fresno, CA 93740-0092, USA, e-mail chrisg@csufresno.edu; Tomas Riad, Department of Scandinavian Languages, Stockholm University, S-10691 Stockholm, Sweden, e-mail tomas.riad@nordiska.su.se.

1. Extensive discussion of Xalilian analysis occurs in, e.g., Freytag (1968 [1830]), Ewald (1825, 1833), Garcin de Tassy (1970 [1873]), Wright (1955 [1898]), and Weil (1958, 1960).

2. The frequency figures are those calculated by Fleisch (1956) on Vadet's (1955) older corpus (hence "I"). We have conflated the figures for rajaz and sari', following Maling (1973: 49).

3. Differences in frequency are the clearest in older, Bedouin poetry. The major patterns are, however, stable even in corpora of later poetry (cf. section 4).

4. We have not here explored constraints on the half-line (see Weil 1960). Many of the variations (zihāfāt 'relaxations' and Gilal 'diseases, defects') discussed in e.g. Maling (1973) should in our view be formulated as edge constraints on the half-line. Ancient Greek meters allow any period-final metrical position to be filled by $\mathrm{L}$ or $\mathrm{H}$, regardless of the meter involved; a similar constraint holds in Arabic meter (Johanson 1994) and is arguably a property of the language as well (Retsö 1994).

5. There is also a strong tendency for metra to have at most one variable position: only rajaz and mudārị contain metra with two. The latter is nonancient and rare. Rajaz is probably the oldest of the ancient meters and was the preferred meter for improvisation (Vadet 1955: 318). Quantitative meter grew out of a tradition of rhymed prose (saj9), and if rajaz is indeed older than the other meters its greater flexibility might well reflect this proselike state. Discussion of the transition from sajৎ to quantitative meter occurs in Borg (1994: chapter 2).

6. Fleisch (1956) omits catalectic variants of meters in his calculations. Including the catalectic figures does not change the figures substantially: țawil $49.87 \%$, kāmil $18.38 \%$, wāfir $13.59 \%$, basīt $10.91 \%$.

7. Stoetzer provides figures based on numbers of lines as well; calculating in this way has no significant impact on the ranking of the various meters.

8. We make no claims about the phonetic nature of stress or the location of word stress in Classical Arabic. (If word stress interacts with meter at all, the relationship is not a 
simple one; e.g. Bloch [1946: 11ff.].) The rhythmic constraints on CLASH and LAPSE hold at the quantitative level, where the organization of moras and syllables into linguistic feet generates prominence patterns.

9. The tendency for heavy syllables to contain a falling sonority curve (closed syllables, diphthongs) reflects this prominence relation; see Kager (1993) for full discussion.

10. We include here each type of metron used in a particular meter.

11. We would like to thank one anonymous reviewer for pointing this out and directing us to the Bauer (1992) corpus.

12. A sequence LL, i.e. two light syllables within the same metrical position, is trochaically stressed, giving [H LL] adjacent stressed syllables [x x.] in violation of CLASH-FT.

13. In view of the discussion in de Bruijn (1994: 36f.) on Persian (and to some extent Arabic) use of xafif, it seems to be the case that features of certain genres later came to be associated with particular meters. But such differentiation had not taken place in early New Persian poetry (Utas 1994: 140), indicating that this is not a factor in the Bedouin poetry considered here.

14. A similar issue arises in prosodic morphology, where Arabic uses both $\mathrm{LH}$ and HL templates, the latter primarily for nominals (broken plurals, masdars), the former for verbals (the binyanim). McCarthy and Prince (1990a) argue that LH is privileged in Arabic and treat it as a basic unit of universal grammar, deriving HL as a complex template composed of two syllables. We follow Kager (1994) in treating both LH and HL templates as complex and understand the iambic advantage as rhythmic (LH doesn't contain a moraic lapse), not as part of UG.

\section{References}

Arberry, A. J. (1965). Arabic Poetry. A Primer for Students. Cambridge: Cambridge University Press.

Bauer, Thomas (1992). Altarabische Dichtkunst. Eine Untersuchung ihrer Struktur und Entwicklung am Beispiel der Onagerepisode, vol. I, chapter 6, "Metrum und Reim," 149-162. Wiesbaden: Harrassowitz.

Bloch, Alfred (1946). Vers und Sprache im Altarabischen. Acta Tropica, suppl. 5. Basel: Verlag für Recht und Gesellschaft.

Borg, Gert (1994). Mit Poesie vertreibe ich den Kummer meines Herzens. Eine Studie zur altarabischen Trauerklage der Frau. Unpublished dissertation, Katholieke Universiteit Nijmegen.

de Bruijn, Johannes T. P. (1994). The individuality of the Persian metre khafif. In Arabic Prosody and its Applications in Muslim Poetry, Lars Johanson and Bo Utas (eds.), 35-43. Uppsala: Almqvist and Wiksell.

Ewald, H. (1825). De metris carminum Arabicorum, libri 2. Braunschweig.

-(1833). Grammatica critica linguae Arabicae, vol. 2, 323-343. Leipzig.

Fleisch, Henri S. J. (1956), L'Arabe classique: Esquisse d'une structure linguistique. Beyrouth: Imprimerie Catholique. (Reprinted 1968. Beyrouth: Dar El-Machareq Éditerus.)

Freytag, Georg Wilhelm (1968 [1830]). Darstellung der arabischen Verskunst. Osnabrück: Biblio.

Garcin de Tassy, Joseph (1970 [1873]). Rhétorique et prosodie des langue de l'orient musulman. Amsterdam: Philo.

Golston, Chris (1994). Constraint based metrics. Paper presented at the 1994 Trilateral Phonology Weekend, Santa Cruz. 
-; and Riad, Tomas (1994). Prosodic metrics. Paper presented at LSA, Boston.

-; and Riad, Tomas (1996). Direct metrics. Paper presented at LSA, San Diego.

Guyard, Stanislas (1876). Théorie nouvelle de la métrique arabe, précédée de considérations générales sur le rhythme naturel du langage, books I-III. Journal Asiatique 7, vol. vii: 413-579, vol. viii: 101-252, 285-315. Paris.

-(1877). Note sur la métrique arabe. Journal Asiatique 7, vol. x: 97-115. Paris.

Halle, Morris (1966). On the metrics of pre-islamic Arabic poetry. Quarterly Progress Report of the Research Laboratory of Electronics 83, 113-116. Cambridge, MA: MIT Press.

Hayes, Bruce (1985). Iambic and trochaic rhythm in stress rules. In Proceedings of the 13th Meeting of the Berkeley Linguistics Society, M. Niepokuj et al. (eds.), 429-446. Berkeley: BLS.

- (1988). Metrics and phonological theory. In Linguistics: The Cambridge Survey, vol. 2, Linguistic Theory: Extensions and Implications, Frederick J. Newmeyer (ed.), 220-249. Cambridge: Cambridge University Press.

-(1995). Metrical Stress Theory: Principles and Case Studies. Chicago: University of Chicago Press.

Jacob, Georg (1967 [1897]). Altarabisches Beduinenleben nach den Quellen geschildert. Hildesheim: Georg Olms.

Johanson, Lars (1994). Introduction: Formal aspects of Sarüd versification. In Arabic Prosody and its Applications in Muslim Poetry, Lars Johanson and Bo Utas (eds.), 7-16. Uppsala: Almqvist and Wiksell.

-; and Utas, Bo (eds.) (1994). Arabic Prosody and its Applications in Muslim Poetry. Swedish Research Institute in Istanbul, Transactions 5. Uppsala: Almqvist and Wiksell.

Kager, René (1993). Alternatives to the iambic-trochaic law. Natural Language and Linguistic Theory 11(3), 381-432.

-(1994). On defining complex templates. In Proceedings of the Twelfth West Coast Conference on Formal Linguistics, E. Duncan, D. Farkas, and P. Spaelti (eds.), 19-34. Stanford, CA: CSLI.

Liberman, Mark; and Prince, Alan (1977). On stress and linguistic rhythm. Linguistic Inquiry 8, 249-336.

Maling, Joan (1973). The theory of classical Arabic metrics. Unpublished dissertation, MIT.

McCarthy, John J. (1979). On stress and syllabification. Linguistic Inquiry 10, 443-465.

-(1981). A prosodic theory of nonconcatenative morphology. Linguistic Inquiry 12, 374-418.

-; and Prince, Alan S. (1986). Prosodic morphology. Unpublished manuscript, University of Massachusetts, Amherst, and Brandeis University.

-; and Prince, Alan S. (1990a). Foot and word in prosodic morphology: the Arabic broken plural. Natural Language and Linguistic Theory 8, 209-282.

-; and Prince, Alan S. (1990b). Prosodic morphology and templatic morphology. In Perspectives on Arabic Linguistics II: Papers from the Second Annual Symposium on Arabic Linguistics, M. Eid and J. McCarthy (eds.), 1-54. Amsterdam and Philadelphia: Benjamins.

-; and Prince, Alan S. (1993). Prosodic morphology I. Unpublished manuscript, University of Massachusetts, Amherst, and Rutgers University.

Nespor, Marina; and Vogel, Irène (1989). On clashes and lapses. Phonology 6, 69-116.

Prince, Alan S. (1983). Relating to the grid. Linguistic Inquiry 14(1), 19-100.

- (1989). Metrical forms. In Rhythm and Meter, Paul Kiparsky and Gilbert Youmans (eds.), 45-80. San Diego, CA: Academic Press.

-; and Smolensky, Paul (1993). Optimality theory: constraint interaction in generative grammar. Unpublished manuscript, Rutgers University and University of Colorado, Boulder. 
Raven, D. S. (1962). Greek Metre. London: Faber and Faber.

Retsö, Jan (1994). The treatment of final syllables in the Classical Arabic metres: the linguistic background. In Arabic Prosody and its Applications in Muslim Poetry, Lars Johanson and Bo Utas (eds.), 99-106. Uppsala: Almqvist and Wiksell.

Selkirk, Elizabeth O. (1984). Phonology and Syntax. Cambridge, MA: MIT Press.

- (1986). On derived domains in sentence phonology. Phonology Yearbook 3, 371-405.

Stoetzer, W. F. (1986). Theory and practice in Arabic metrics. Unpublished dissertation, University of Leiden.

Utas, Bo (1994). Arabic and Iranian elements in New Persian prosody. In Arabic Prosody and its Applications in Muslim Poetry, Lars Johanson and Bo Utas (eds.), 129-141. Uppsala: Almqvist and Wiksell.

Vadet, Jean (1955). Contribution à l'histoire de la métrique arabe. Arabica 2, 313-321.

Weil, Gotthold (1958). Grundriss und System der altarabischen Metren. Wiesbaden: Harrassowitz.

-(1960). Garū I. I. In The Encyclopedia of Islam, 2nd ed., 667-677. Leiden: Brill.

West, M. L. (1985). Greek Metre. Oxford: Clarendon.

Wright, William (1955 [1898]). A Grammar of the Arabic Language, vol. II, part 4, "Prosody," 350-390. Cambridge: Cambridge University Press. 
Copyright of Linguistics is the property of Walter de Gruyter $\mathrm{GmbH}$ \& Co. KG. and its content may not be copied or emailed to multiple sites or posted to a listserv without the copyright holder's express written permission. However, users may print, download, or email articles for individual use. 